\title{
Association Between Neonatal Hyperbilirubinemia and Serum Zinc Levels in Dhaka City of Bangladesh
}

\author{
Mohammad Anwar Hossain ${ }^{1}$, Mohammad Nazmul Huda ${ }^{2, ~ *, ~ M o h a m m a d ~ E k r a m u l ~ I s l a m ³, ~}$ \\ Ashik Mosaddik ${ }^{3}$, Saiful Islam ${ }^{4}$, Quddusur Rahman ${ }^{4}$, Firoza Begum ${ }^{5}$, Sheikh Mizanur Rahman ${ }^{6}$, \\ Tarun Kanti Paul ${ }^{7}$ \\ ${ }^{1}$ Institute of Biological Sciences, Rajshahi University, Rajshahi, Bangladesh \\ ${ }^{2}$ Department of Ayurvedic Medicine, Government Unani and Ayurvedic Medical College and Hospital, Dhaka, Bangladesh \\ ${ }^{3}$ Department of Pharmacy, Rajshahi University, Rajshahi, Bangladesh \\ ${ }^{4}$ Department of Laboratory Medicine, Bangabandhu Sheikh Mujib Medical University, Dhaka, Bangladesh \\ ${ }^{5}$ Department of Fetomaternal Medicine, Bangabandhu Sheikh Mujib Medical University, Dhaka, Bangladesh \\ ${ }^{6}$ Department of Microbiology, Institute of Public Health, Dhaka, Bangladesh \\ ${ }^{7}$ Department of Microbiology, Sylhet Muhammad Ataul Gani Osmani Medical College, Sylhet, Bangladesh
}

\section{Email address}

mdnazmulhudabd@yahoo.com (M. N. Huda)

${ }^{*}$ Corresponding author

\section{To cite this article:}

Mohammad Anwar Hossain, Mohammad Nazmul Huda, Mohammad Ekramul Islam, Ashik Mosaddik, Saiful Islam, Quddusur Rahman, Firoza Begum, Sheikh Mizanur Rahman, Tarun Kanti Paul. Association Between Neonatal Hyperbilirubinemia and Serum Zinc Levels in Dhaka City of Bangladesh. American Journal of Laboratory Medicine. Vol. 5, No. 6, 2020, pp. 174-179. doi: 10.11648/j.ajlm.20200506.14

Received: November 21, 2020; Accepted: December 9, 2020; Published: December 16, 2020

\begin{abstract}
Neonatal hyperbilirubinemia is a common clinical condition in the first week of neonatal life. The common causes are haemolytic disease of the newborn (rhesus), ABO incompatibility, glucose-6-phosphate dehydrogenase deficiency, spherocytosis and infection. Any study was not conducted in Bangladesh to find out the correlation between neonatal hyperbilirubinemia and zinc level. So, the objective of this was to evaluate the correlation between the level of serum zinc and neonatal hyperbilirubinemia in Dhaka city of Bangladesh. This cross sectional study was done at Bangabandhu Sheikh Mujib Medical University (BSMMU), Dhaka, Bangladesh. Total 594 numbers of sample were collected from neonatology department of BSMMU from January 2016 to April 2019 and samples were divided in two groups. Case group and control group consists 319 and 275 numbers of sample respectively. All the laboratory parameters were done at clinical pathology department of BSMMU by automated analyzer machine and strictly followed quality control. Data obtained were analyzed using the Statistical Package for the Social Science (SPSS) version 20. Results were considered statistically significant if $\mathrm{p}<0.05$. The result showed that the level of serum bilirubin was $171.14 \mathrm{mg} / \mathrm{L}$ and $35.42 \mathrm{mg} / \mathrm{L}$ and the level of serum zinc was $(0.50 \mathrm{mg} / \mathrm{L})$ and $(0.68 \mathrm{mg} / \mathrm{L})$ in case and control group respectively. The bilirubin level was significantly $(\mathrm{p}<0.001)$ high in case group and zinc level was significantly $(\mathrm{p}<0.001)$ decreased in case group when compared with control group. Is also showed there was a significant $(\mathrm{p}$ value $<0.001$ ) correlation between hyperbilirubinemia and serum zinc level in this study. Therefore, it can be concluded, the deficiency of zinc may have a relationship followed by in neonatal hyperbilirubinemia.
\end{abstract}

Keywords: Neonatal, Hyperbilirubinemia, Serum Zinc, Severe Neonatal Jaundice (NNJ)

\section{Introduction}

When a newborn has an excessive amount of bilirubin in the blood that causes the yellowish discoloration of skin, eyes and mucous membrane of body called neonatal hyperbilirubinemia. Neonatal jaundice is another term of neonatal hyperbilirubinemia. [1] Neonatal hyperbilirubinemia is a leading clinical condition for hospital admission throughout the first week of life of newborn babies. Globally it affects about 84-112 million neonates, out of them approximately $60 \%$ full term and $80 \%$ preterm 
babies in their first 2 week of life. [2] Usually neonatal jaundice is self-limiting and not an injurious condition; but severe condition may cause permanent brain damage in association with behavioral and neurological impairment. [3] Many causes such as haemolytic disease of the newborn (rhesus), ABO incompatibility, glucose-6-phosphate dehydrogenase deficiency, spherocytosis and infection are responsible for neonatal jaundice. [4] Furthermore, abnormal level of trace elements like zinc, copper and magnesium might disturb the bilirubin metabolism and excretion. [5]

Zinc is an important trace element for cellular function of human body by maintaining nucleic acid metabolism, protein synthesis, and enzymatic activation. [6] Its deficiency may cause growth retardation, congenital malformations, neurological disorders, and precipitate infections. [7]

In Bangladesh, bilirubin-induced mortality is significantly more important in early age of neonate. [8] However; more information or data is not obtainable to find out the exact causes or situation of newborn jaundice. [9] So this present study was carried out to find out the characteristics of the neonatal jaundice and any relation of heavy metals like serum zinc with newborn hyperbilirubinemia at Dhaka City in Bangladesh.

\section{Materials \& Methods}

\subsection{Study Design}

This cross sectional study was done at Bangabandhu Sheikh Mujib Medical University (BSMMU), Dhaka, Bangladesh.

\subsection{Sample Size and Grouping}

Total 594 samples and those residences in Dhaka city were collected from Department of Clinical Pathology (Laboratory Medicine) and Neonatology were divided 319 in case group and 275 control group.

\subsection{Blood Collection and Serum Separation}

Two milliliter $(2 \mathrm{ml})$ blood was collected from neonate under complete aseptic conditions and was dispensed into a plain tube left to clot at room temperature $\left(25^{\circ} \mathrm{C}\right)$ for 30 minutes, centrifuged in $3000 \mathrm{rpm}$ for 5 minutes, then the serum was separated and stored in $-20^{\circ} \mathrm{C}$ for further test.

\subsection{Estimation of Serum Bilirubin}

The level of bilirubin was assessed by photometric automated methods (Dimension RxL Max, USA) at $540 \mathrm{~nm}$ and measured absorbs using a bichromatic (540, $700 \mathrm{~nm}$ ) endpoint technique. [10]

Solubilized bilirubin + Diazotized sulfanilic acid $\overrightarrow{\text { (absorbs at } 540 \mathrm{~nm})}$ Red chromophore

\subsection{Estimation of Serum Zinc}

Zinc was assessed by colorimetric method (Semi-automated biochemistry analyzer, Evolution 3000, Italy) using ready for use kit (Egypt) in the Zinc produces with 5-Br-PAPS [(2-5Brom-2-pyridylazo)-5-(N-propyl-N-sulfopropyl-amino)phenol] a stable coloured complex which colour intensity is directly proportional to the amount of zinc in the sample. [11]

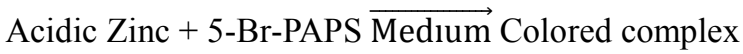

\subsection{Data Processing and Analysis}

Data were noted in predefined report forms, later compiled to analyze the data using latest version statistical package for the social sciences (SPSS) software to obtain the mean, standard deviation and frequencies.

\section{Result}

\subsection{Demographic Variables}

The demographic variables of age, sex, weight, mother's occupation and antenatal checkup of all neonates has been compared to the control groups. The mean age of the respondents was $3.08 \pm 2.80$ and $3.21 \pm 3.65$ days in study and control respectively which is not significant. In sex determination male were 187 and 160 in case and control group respectively and female were 132 and 115 in case and control group respectively. The highest percentage of male were $58.6 \%$ in case and $58.18 \%$ in control group followed by female population both in case and control group which is not significant. The mean weight was $2.62 \pm 0.37$ kilogram in case group and $2.84 \pm 0.27$ kilogram in control group which was significantly highest 2.5-3.5 kilogram in case group. Table 1 also showed that highest numbers of mother's occupation were housewife 240 in case group and 218 in control group which was not significant. Antenatal checkup variable of mothers was regular checkup 301 and 258 in case and control group respectively. In respect to socioeconomic status, 225 numbers of mother of case group and 173 numbers of mother of control group come from upper middle class family.

Table 1. Demographic variables of case and control groups ( $n=594)$.

\begin{tabular}{llll}
\hline Demographic variables & Case $(\mathbf{n}=\mathbf{3 1 9}) \mathbf{N}(\mathbf{\%})$ & Control $(\mathbf{n}=\mathbf{2 7 5}) \mathbf{N}(\mathbf{\%})$ & $\boldsymbol{p}$ value \\
\hline Age (days) & & & \\
$1-2$ & $178(55.80)$ & $175(63.64)$ & $70(25.45)$ \\
$3-7$ & $115(36.05)$ & $27(9.82)$ & $3(1.09)$ \\
$8-15$ & $24(7.52)$ & $3.21 \pm 3.65$ & \\
Up to 25 & $2(0.63)$ & $0.94^{\mathrm{ns}}$ \\
Mean \pm SD & $3.08 \pm 2.80$ & & \\
\hline
\end{tabular}




\begin{tabular}{llll}
\hline Demographic variables & Case $(\mathbf{n}=\mathbf{3 1 9}) \mathbf{N}(\mathbf{\%})$ & Control (n=275) N (\%) & p value \\
\hline Sex & & & \\
Male & $187(58.62)$ & $160(58.18)$ & $115(41.82)$ \\
Female & $132(41.38)$ & & \\
Weight $(\mathrm{kg})$ & & $207^{\mathrm{ns}}$ \\
$<2.5$ & $90(28.21)$ & $2(0.73)$ \\
$2.5-3.5$ & $227(71.16)$ & $2(0.73)$ \\
$>3.5$ & $2(0.63)$ & $2.84 \pm 0.27$ \\
Mean \pm SD & $2.62 \pm 0.37$ & \\
Mothers Occupation & & $218(79.27)$ \\
House wife & $240(75.23)$ & $40(14.55)$ \\
Service & $58(18.18)$ & $17(6.18)$ \\
Business & $21(6.58)$ & \\
Mean \pm SD & & \\
Antenatal checkup & & $258(98.82)$ \\
Regular & $301(94.36)$ & $17(6.18)$ \\
Irregular & $18(5.64)$ & \\
Mean \pm SD & & 18 \\
Socio-economic status & & 67 \\
$<10000$ (Lower) & 07 & 173 \\
10001-20000 (Lower middle) & 58 & 17 \\
20001-40000 (Upper middle) & 225 & \\
$>40000$ (Upper) & 29 & \\
Mean \pm SD & & $0.23^{\mathrm{ns}}$ \\
\hline
\end{tabular}

Note: $s=$ significant; $n s=$ not significant, $a$; $P$ value reached from unpaired t-test, $b$; P value reached from Chi square test

\subsection{Serum Bilirubin Level}

The concentration of serum bilirubin was $171.14 \mathrm{mg} / \mathrm{L}$ and $35.42 \mathrm{mg} / \mathrm{L}$ in case and control group respectively and which is very significant $(\mathrm{p}<0.001)$ when case group compared with control group in neonates.

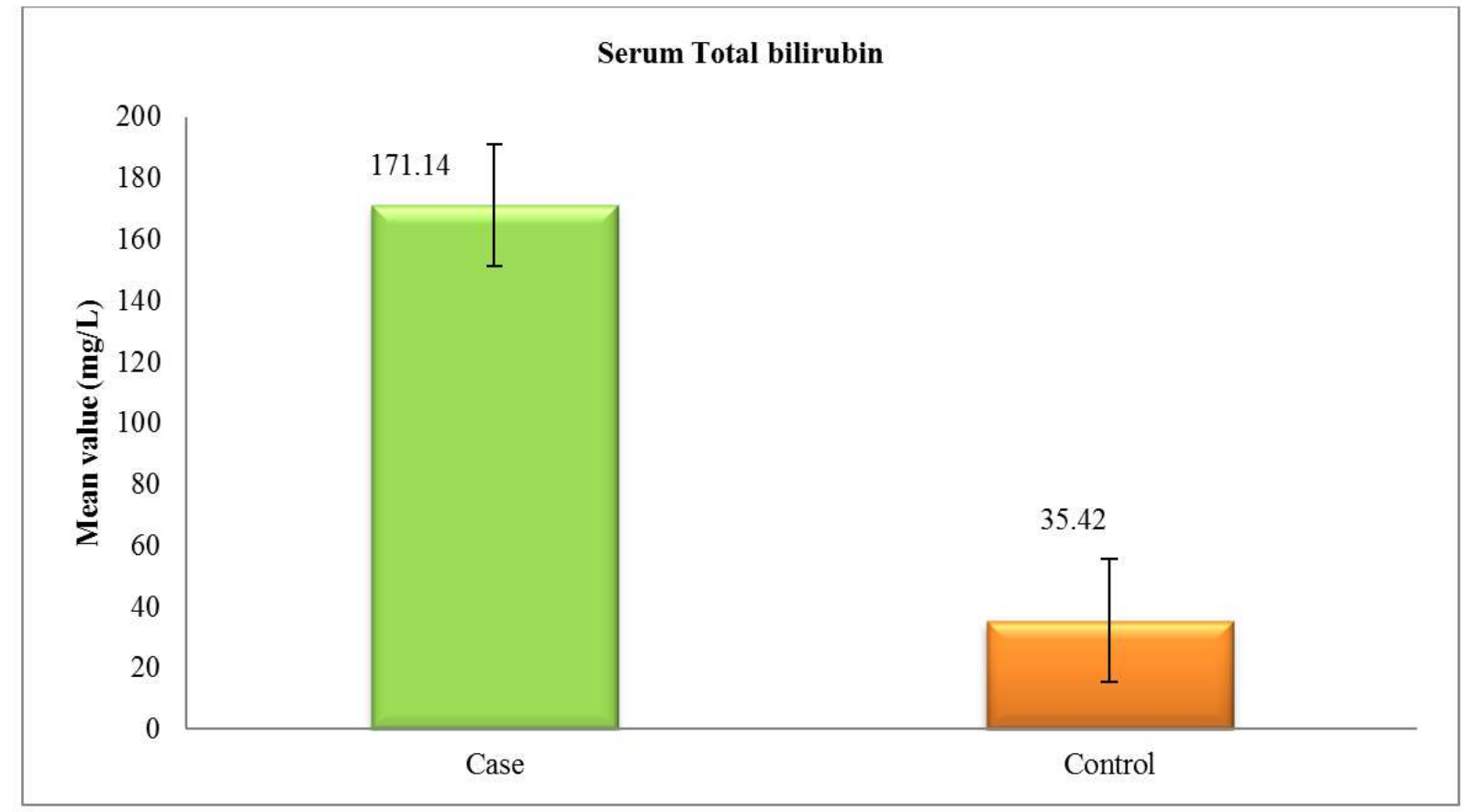

Figure 1. The concentration of serum bilirubin level.

\subsection{Serum Zinc Level}

Serum Zinc result is lower in cases $(0.50 \mathrm{mg} / \mathrm{L})$ than control group $(0.68 \mathrm{mg} / \mathrm{L})$. The concentration of serum zinc is lower in case group when is compared with control which is very significant $(\mathrm{p}<0.001)$. 


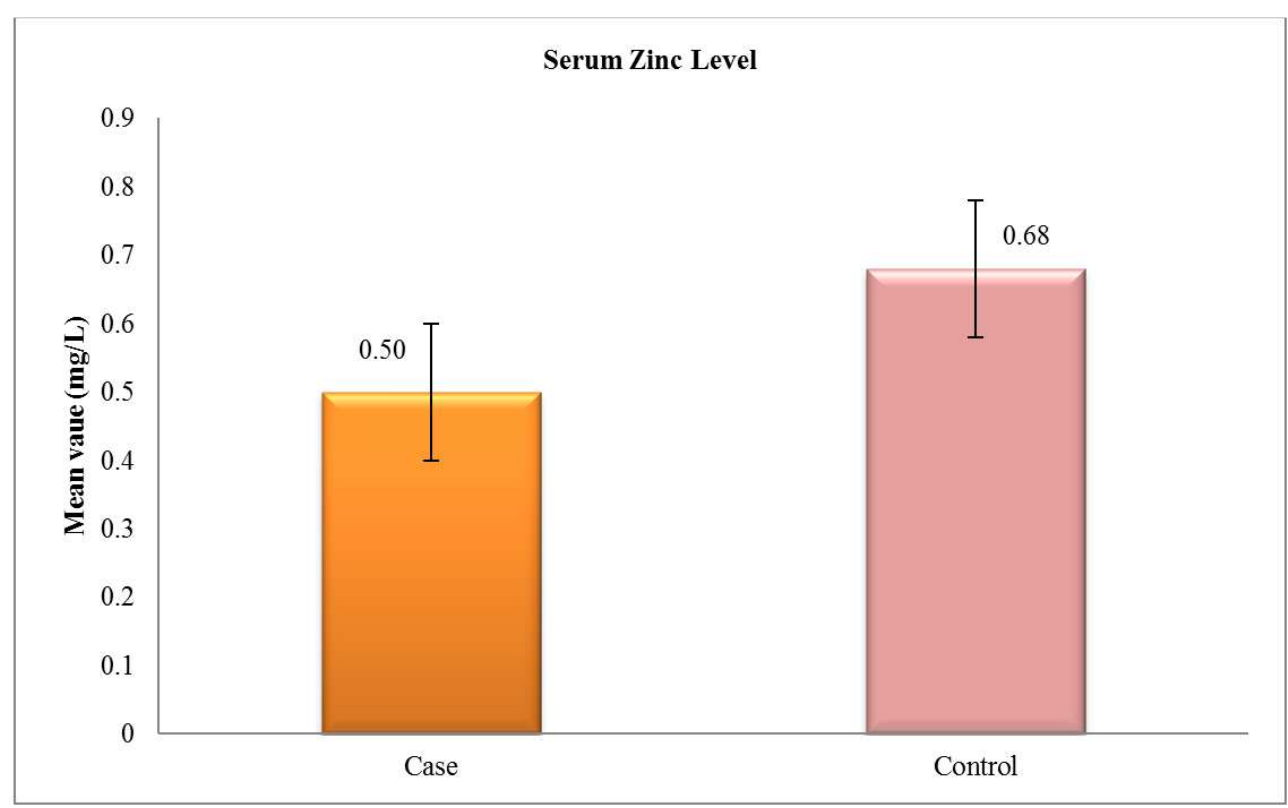

Figure 2. The concentration of serum zinc level.

\subsection{Mean Difference Between Serum Bilirubin and Zinc Level}

Total serum bilirubin, zinc level was estimation of all neonates and compared to the control group. Table 2 showed that the total serum bilirubin was higher in case group
$(171.14 \pm 17.08) \mathrm{mg} / \mathrm{L}$ than control group $(35.42 \pm 8.38)$ $\mathrm{mg} / \mathrm{L}$. The level of serum zinc was lower in case group $(0.50$ $\pm 0.03) \mathrm{mg} / \mathrm{L}$ than control group $(0.68 \pm 0.10) \mathrm{mg} / \mathrm{L}$. It is highly significant $(\mathrm{p}<0.001)$ when for all serum level in case group compared with control group.

Table 2. Mean difference Serum total bilirubin, Zinc between Cases and Control Group.

\begin{tabular}{|c|c|c|c|}
\hline Trace Elements & Case $(n=319)$ Mean \pm SD & Control $(n=275)$ Mean \pm SD & p value \\
\hline Serum total bilirubin $(\mathrm{mg} / \mathrm{L})$ & $171.14( \pm 17.08)$ & $35.42( \pm 8.38)$ & $<0.001^{\mathrm{s}}$ \\
\hline Serum Zinc $(\mathrm{mg} / \mathrm{L})$ & $0.50( \pm 0.03)$ & $0.68( \pm 0.10)$ & $<0.001^{\mathrm{s}}$ \\
\hline
\end{tabular}

Note: $\mathrm{s}=$ significant; $\mathrm{ns}=$ not significant, $\mathrm{p}<0.001$

\subsection{Correlation Between Serum Bilirubin with Zinc Level}

In figure 2 the scatter diagram showing negative significant pearson correlation $(\mathrm{r}=-0.773, \mathrm{p}$ value $<0.001)$ between serum total bilirubin level and serum zinc level in both groups. It is justified that if serum bilirubin level is increased, the serum zinc level decreased in case group and control group.

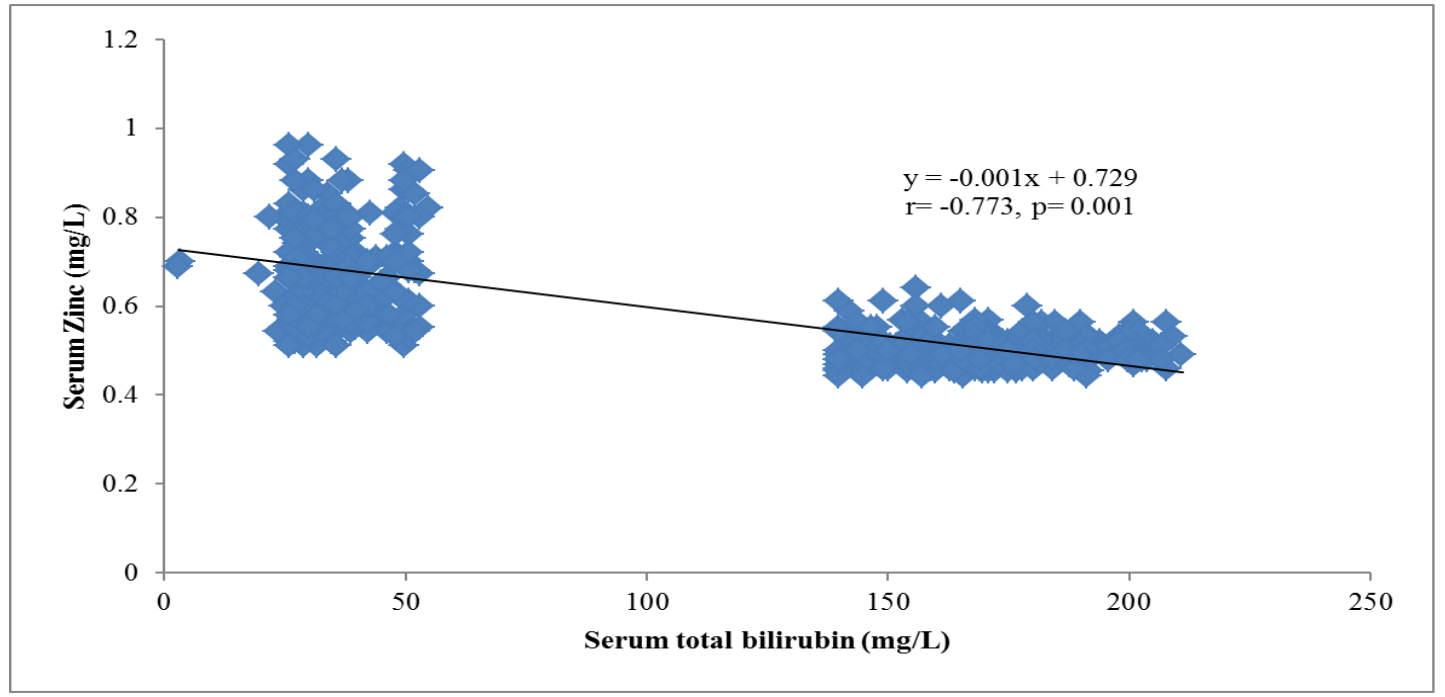

Figure 3. Scatter diagram of correlation between total bilirubin and zinc level. 


\section{Discussion}

The result of this study found that the highest incidence was in age group 2.5 to 3.5 days of neonates in both groups. Many past studies revealed that hyperbilirubinemia is more common in first week of postnatal period. [12] This present study showed that serum zinc level was significantly $(\mathrm{p}<0.001)$ lower in case group $(0.50 \pm 0.03 \mathrm{mg} / \mathrm{L})$ when compared with control group $(0.68 \pm 0.10 \mathrm{mg} / \mathrm{L})$, and correlation between hyperbilirubinemia and zinc also significant when $p$ value is $<0.001$.

Zinc is an essential micronutrient for human body that mainly absorbed in small intestine. It is necessary for various enzymatic reaction, cell growth, apoptosis and bilirubin metabolism. [13]

Zinc also act as an antioxidant and contribute to protection of oxidative stress for maintaining cellular function. [14] Zinc have the ability to regulate the lipid metabolism by activate the peroxisome proliferator-activated receptor- $\alpha$ $($ PPAR- $\alpha)$ and that may modulate the erythrocyte membrane [15]

Long term zinc deficiency is responsible for advanced liver disease like cirrhosis, idiopathic hyperbilirubinemia by the mechanism of decreased serum albumin synthesis, increase oxidative stress, diminished hepatic extraction, portosystemic shunts, and losses in urine. [16]

Zinc deficiency in neonatal hyperbilirubinemia may cause the disturbance of bilirubin synthesis due to deficient synthesis of some enzymes and also causes for the destruction of erythrocyte membrane that leads to hemolytic jaundice. [17]

The another study also presented that zinc salts may help to inhibit the hem-oxygenase enzymes resulting to prevent enterohepatic circulation of bilirubin. [18] Therefore, the present study appears that zinc have a significant defending effects in the case of neonatal hyperbilirubinemia.

\section{Conclusion}

The lower level of zinc concentration is accountable for many diseases including neonatal hyperbilirubinemia. The findings of this study indicated that zinc may have a close relation with neonatal jaundice.

\section{Recommendation}

This work has done with many limitations. So future study should consider the following points before starting the work. The future study can be done in multicenter study in rural and urban or slum area of Bangladesh along with more sample size. Trace element selenium (Se), chromium $(\mathrm{Cr})$, cobalt $(\mathrm{Co})$, iodine (I), manganese $(\mathrm{Mn})$, and molybdenum (Mo) should be taken in further study. Some others history like dietary, family history, drug history of mother should be included in future study. Molecular study can be done in hyperbilirubinemia patient in newborn.

\section{Acknowledgements}

Acknowledge to the Department of Clinical Pathology and Department of Neonatology, Bangabandhu Sheikh Mujib Medical University, Dhaka, Bangladesh for their supports for data collection. Special thanks to Institute of Biological Sciences, Rajshahi University, Bangladesh for input and analysis of data and others official support to do this study.

\section{References}

[1] Medical Definition of Neonatal hyperbilirubinemia [Internet] 2019 June 4 [updated 2018 October 6; cited 2019 Nov 13]. Available from: https://www.medicinenet.com/script/main/art.asp?articlekey=1 6385

[2] Olusanya BO, Kaplan M, Hansen TWR. Neonatal hyperbilirubinaemia: a global perspective. Lancet Child Adolesc Health. 2018 Aug; 2 (8): 610-620.

[3] Brits H, Adendorff J, Huisamen D, Beukes D, Botha K, Herbst $\mathrm{H}$, Joubert $\mathrm{G}$. The prevalence of neonatal jaundice and risk factors in healthy term neonates at National District Hospital in Bloemfontein. Afr J Prm Health Care Fam Med. 2018; 10 (1), a1582.

[4] Abd El Moktader AM., Hussein SK., Boraik Mohamed GM. Hyperbilirubinemia in Neonatal Intensive Care Unit: Incidence and Etiology at Fayoum University Hospital. Fayoum University Medical Journal, 2019; 3 (2): 8-14.

[5] El-Mazary AA, Abdel Aziz RA, Sayed MA, Mahmoud RA, Saidii AA. Effect of Intensive Phototherapy and Exchange Transfusion on Copper, Zinc and Magnesium Serum Levels in Neonates with Indirect Hyperbilirubinemia. Int J Pediatr 2017; 5 (2): 4371-83.

[6] Ali SR, Abdel-aal M, Elsamanoudy M, Ibrahim S. Serum Zinc Level in Neonates with Indirect Hyperbilirubinemia. IJMA 2020; 2 (1): 217-222.

[7] Ahmadpour-Kacho M, Zahed Pasha Y, Khafri S, OmidbakhshAmiri S, Tehrani S. Correlation between Prolonged Hyperbilirubinemia and Serum Zinc Level in Term Neonates. Iranian Journal of Neonatology. 2019 Dec: 10 (4). DOI: 10.22038/ijn.2019.37384.1578

[8] Olusanya BO, Teeple S, Kassebaum NJ. The Contribution of Neonatal Jaundice to Global Child Mortality: Findings from the GBD 2016 Study. Pediatrics. 2018; 141 (2): e20171471.

[9] Zabeen B, Nahar J, Nabi N, Baki A, Tayyeb S, Azad K, Nahar N. Risk Factors and Outcome of Neonetal Jaundice in a Tertiary Hospital. Ibrahim Med. Coll. J. 2010; 4 (2): 70-73.

[10] Siemens Healthcare Diagnostics Inc, Newark, DE 19714, U.S.A. Available at: www.siemens.com/diagnostics.

[11] Johnsen O, Eliasson R. Evaluation of a commercially available kit for the colorimetric determination of zinc in human seminal plasma. Int J Androl, 1987; 10: 435-440. 
[12] Gregory MLP, Martin CR, Cloherty JP. Neonatal hyperbilirubinemia. In: Cloherty JP, Eichenwald EC and Stark AR (eds). Manual of Neonatal Care, $7^{\text {th }}$ ed. Chapter 26, Lippincott- Raven Philadelphia 2012. 304-339.

[13] Andree H. Koop, Omar Y. Mousa, Ly Elaine Pham, Juan E. Corral-Hurtado, Surakit Pungpapong, Andrew P. Keaveny. An Argument for Vitamin D, A, and Zinc Monitoring in Cirrhosis. Annals of Hepatology, 2018; 17 (6): 920-932.

[14] Marreiro DD, Cruz KJ, Morais JB, Beserra JB, Severo JS, de Oliveira AR. Zinc and Oxidative Stress: Current Mechanisms. Antioxidants (Basel). 2017; 6 (2): 24.

[15] Himoto T, Masaki T. Current Trends of Essential Trace Elements in Patients with Chronic Liver Diseases. Nutrients. 2020; 12 (7): 2084.
[16] Kozeniecki M, Ludke R, Kerner J, Patterson B. Micronutrients in Liver Disease: Roles, Risk Factors for Deficiency, and Recommendations for Supplementation. Nutr Clin Pract. 2020 Feb; 35 (1): 50-62.

[17] Méndez-Sánchez N, Martínez M, González V, Roldán-Valadez E, Flores MA, Uribe M. Zinc sulfate inhibits the enterohepatic cycling of unconjugated bilirubin in subjects with Gilbert's syndrome. Ann Hepatol, 2002 Jan-Mar; 1 (1): 40-3.

[18] Boskabadi H, Maamouri G, Mohsen Zadeh H, Shakeri M, Ghayour-Mobarhan M, et al. Comparison of Serum Zinc Level Between Neonates With Jaundice and Healthy Neonates, Shiraz E-Med J. 2015; 16: 11-12. 